\title{
Addition of conjugated linoleic acid in whole milk improves lipid profile in high fat diet induced hypercholesterolemia of rats
}

\author{
Arta Farmawati ${ }^{1 *}$, Rio Jati Kusuma ${ }^{2}$, Bayu Sigha Iswara ${ }^{2}$, Wulandari ${ }^{2}$, Kurniati Dwi Utami ${ }^{2}$, \\ Istiti Kandarina ${ }^{3}$ \\ ${ }^{1}$ Department of Biochemistry, ${ }^{2}$ Department of Nutrition and Health, ${ }^{3}$ Department of \\ Biostatistic Epidemiology Population Health, Faculty of Medicine, Universitas Gadjah \\ Mada, Yogyakarta, Indonesia
}

DOI: http://dx.doi.org/10.19106/JMedSci004804201601

\section{ABSTRACT}

Conjugated linoleic acid (CLA) is an isomer of linoleic acid that has been shown to have many beneficial effects in prevention of atherosclerosis, hypertension, cardiovascular diseases and improve immune function. Although majority of CLA in the diet are derived from dairy product such as milk, however, the content of CLA in milk is affected by cow's diet. The aim of this study was to investigate the beneficial effect of CLA supplementation in milk for improving lipid profile in high fat diet of rats. Twenty four male Sprague Dawley rats aged 8 weeks were given high fat diet for 3 weeks to induce hypercholesterolemia. Six rats were maintained in standard diet as control. Rats then were divided into 4 groups i.e. normal control, negative control, high fat diet + CLA 0.5\%, high fat diet + CLA 0.5\% supplemented skim milk, and high fat diet + CLA 0.5\% supplemented whole milk. Blood sample was drawn after high fat diet induced hypercholesterolemia and after 4 weeks of treatment for total cholesterol, triglyceride, low-density lipoprotein cholesterol (LDL cholesterol), and high density lipoprotein cholesterol (HDL cholesterol) analysis. Body weight was measured each week. Results showed that body weight was significantly increase in all groups received high fat diet $(p<0.05)$. There was no significant difference in body weight between treatment group $(p>0.05)$. Total cholesterol, triglyceride, and LDL cholesterol was significantly decrease in whole milk followed by significant increase in HDL cholesterol level. Skim milk supplemented with CLA had only modest effect on triglyceride and HDL cholesterol level. In conclusion, CLA supplementation in whole milk improves lipid profile in high fat diet.

\section{ABSTRAK}

Asam linoleat terkonjugasi adalah isomer asam linoleat yang terbukti mempunyai manfaat dalam mencegah aterosklerosis, hipertensi, penyakit kardiovaskuler dan meningkatkan sistem imun. Meskipun sebagian besar asam linoleat dalam diet berasal dari produk makanan sehari-hari seperti susu, namum demikian kandungan asam linoleat dalam susu dipengaruhi oleh diet sapi penghasil susu. Penelitian ini bertujuan untuk mengkaji manfaat asam linoleat dalam suplemen susus dalam memperbaiki profil lipid pada tikus diet lemak tinggi. Dua puluh empat tikus jantan Sprague Dawly berumur 8 minggu diberi diet lemak tinggi selama 3 minggu untuk menginduksi hiperkolesterolemia. Enam ekor tikus diberi diet makan standar sebagai control. Tikus kemudian dibagi menjadi empat kelompok yaitu kelompok kontrol normal, kelompok kontrol negatif, kelompok diet tinggi lemak dengan 


\begin{abstract}
asam linoleat $0.5 \%$, kelompok diet tinggi lemak dengan asam linoleat $0.5 \%$ dalam suplemen susu skim, kelompok diet tinggi lemak dengan asam linoleat $0.5 \%$ dalam suplemen susu susu murni. Sampel darah diambim setelah diet induksi hiperkolesterolemia dan setelah empat minggu perlakuan untuk ditetapkan kadar kolesterol total, trigliserida, low density lipoprotein cholesterol (kolesterol LDL) dan low density lipoprotein cholesterol (kolesterol HDL). Berat badan tikus diukur setiap minggu. Hasil penelitian menunjukkan berat badan meningkat secara nyat di semua kelompok $(p<0,05)$. Tidak terdapat perbedaan berat badan tikus di semua kelompok $(p>0,05)$. Kadar kolesterol total, trigliserid dan kolesterol LDL menurun secara bermakna pada kelompok yang diberi susu murni dengan asam linoleat, sedangkan kadar kolesterol HDL meningkat secara nyata $(p>0,05)$. Kelompok yang diberi susu skim dengan asam liinoleat mempunyai pengaruh moderat terhadap kadar trigliserida dan kolesterol HDL. Dapat disimpulkan, suplemen asam linoleat dalam susu murni dapat memperbaiki profil lipid tikus yang diberi diet tinggi lemak.
\end{abstract}

Key words: conjugated linoleic acid - hypercholesterolemia - lipid profile - milk - diet

\section{INTRODUCTION}

The pandemic rise of obesity has continued both in economically developed country as well in economically developing country. In United States, the prevalence of obesity among US adult has rise from $23 \%$ in 1988 to $30.5 \%$ in 2000 and $33.8 \%$ in $2008 .{ }^{1,2}$ In Australia, the proportion of children with severe obesity has risen significantly from $19.3 \%$ in 1985 to $32.0 \%$ in $2012 .^{3}$ The rise in the prevalence of children with obesity was also observed in Indonesia from $10.3 \%$ in 1993 to $16.5 \%$ in $16.5 \%$ in $2007 .{ }^{4}$ High prevalence of obesity has been linked with high risk the development of metabolic syndrome, ${ }^{5}$ which is a major risk factor for cardiovascular disease, chronic kidney disease, type 2 diabetes, cancer, and inflammatory bowel disease. ${ }^{6-8}$

Impairment in lipid metabolism and oxidative stress have been reported in obese individual. ${ }^{9,10}$ Disturbance in adiposityreleasing hormone or adipokines is one contributing factor in the development of dyslipidemia indicated by elevated level of triglycerides and low HDL cholesterol in obesity. ${ }^{11}$ Reducing body weight has been linked with significant improvement in cardiovascular risk factor such as improved glycemia, blood pressure, triglycerides, and HDL cholesterol. ${ }^{12}$

Conjugated linoleic acid (CLA) is a type of isomeric-geometrical group of linoleic acid, which predominantly found in dairy product (milk, butter, yogurt, and cheese), meat, and meat product of ruminant. ${ }^{13,14}$ This type of fat can promote several health beneficial effect in preventing several diseases such as aterosclerosis, cancer and diabetes. ${ }^{15-17}$ It also has been reported to reduce body weight although the evidence is controversial. ${ }^{15,18}$ Here, we evaluated the effect of CLA supplementation in milk in lipid profile and body weight of rats fed high fat diet.

\section{MATERIALS AND METHODS}

\section{Preparation of CLA supplemented milk}

Skim milk or whole milk was obtained from local market in dry form. Conjugated linoleic acid isomers used is $37-42 \%$ cis-9 trans-11 (c9t11) and 37-42\% trans-10 cis12 (t10c12). Supplementation CLA used consisted of $80 \%$ pure CLA with the addition of gelatin, glycerin, distilled water, and the color of caramel to $100 \%$. The energy content 
of the CLA is $10 \mathrm{kcal} /$ capsule. Conjugated dietary supplement was obtained from Ultima Central Jakarta.

\section{Animal and diet}

Thirty male Sprague Dawley rats aged 6 weeks with average weight of $100 \mathrm{~g}$ were obtained from Department of Pharmacology and Therapy, Faculty of Medicine, Universitas Gadjah Mada, Yogyakarta. Rats were maintained in individual steel cage with 12 hour light cycle. Rats were acclimatized for three days prior to experiment. After adaptation period, 24 rats were subjected to high fat diet for three weeks and six rats were fed standard diet as control. The high fat diet was derived from AIN-93M semi purified diet that consist $20 \%$ of lard plus $3 \mathrm{~mL}$ of egg yolk through oral gavage/day. The composition of the diet was presented at TABLE 1 .

TABLE 1. Diet composition (g/kg diet)

\begin{tabular}{lcc}
\hline Composition & Standard diet & High fat diet \\
\hline Cornstarch & 465.69 & 15.69 \\
Dextrinized cornstarch & 155.00 & 155.00 \\
Casein & 140.00 & 140.00 \\
Sucrose & 100.00 & 100.00 \\
Soybean oil & 40.00 & 40.00 \\
Alphacel & 50.00 & 50.00 \\
Mineral mix (AIN-93M) & 35.00 & 35.00 \\
Vitamin mix (AIN-93M) & 10.00 & 10.00 \\
L-cystine & 1.80 & 1.80 \\
Choline bitartrate & 2.50 & 2.50 \\
TBHQ & 0.08 & 0.08 \\
Lard & - & 200.00 \\
\hline Calories & 3849.96 & 3849.96 \\
\hline
\end{tabular}

After 3 weeks of high fat diet, rats were divided into 5 groups: standard diet (normal control), high fat diet (negative control), high fat diet + CLA 0.5\% (CLA-0.5), high fat diet + CLA supplemented skim milk $0.5 \%$ (CLA-Skim 0.5\%), high fat diet + CLA supplemented whole milk $0.5 \%$ (CLAWhole $0.5 \%$ ). Intervention was carried out for 4 weeks. CLA $0.5 \%$ was prepared by dissolution of $95.50 \mathrm{mg}$ of CLA with $100 \mathrm{~mL}$ of water and homogenized. All CLA and CLA supplemented milk were given by oral gavage in $2 \mathrm{~mL}$ of water/milk. Blood sample was taken after high fat diet intervention as pre-test and after 4 weeks of intervention as post-test for lipid profile (total cholesterol, triglyceride, HDL cholesterol and LDL cholesterol) analysis. Body weight was weighed every week. All procedures have been approved by the Medical and Health Research Ethics Committee of Faculty of Medicine, Univesitas Gadjah Mada, Yogyakarta (No. KE/FK/385/ EC/2009).

\section{Lipid profile analysis}

Blood sample was taken and immediately centrifuged at 4,000 rpm to obtain serum. Total cholesterol and triglyceride were assessed 
using enzymatic colorimetric method using total cholesterol and triglyceride kit according to manufacturer protocol. LDL cholesterol and HDL cholesterol were precipitated prior to the analysis.

\section{Statistical analysis}

Data were presented as mean \pm standard deviation (SD) and analysed by analysis of variance (ANOVA) followed by paired t-test. A $p<0.05$ was considered to be statistically significant. All data analysis were performed by using SPSS 17.0 (SPSS Inc).

\section{RESULTS \\ Impact on CLA-supplemented milk on body weight}

Body weight did not significantly different $(p>0.05)$ between groups during high fat diet-induced obesity as well as in week 1 intervention. Significant difference $(p<0.05)$ in body weight was observed only in control group compared with other during week 2 up to week 4 intervention (FIGURE 1).

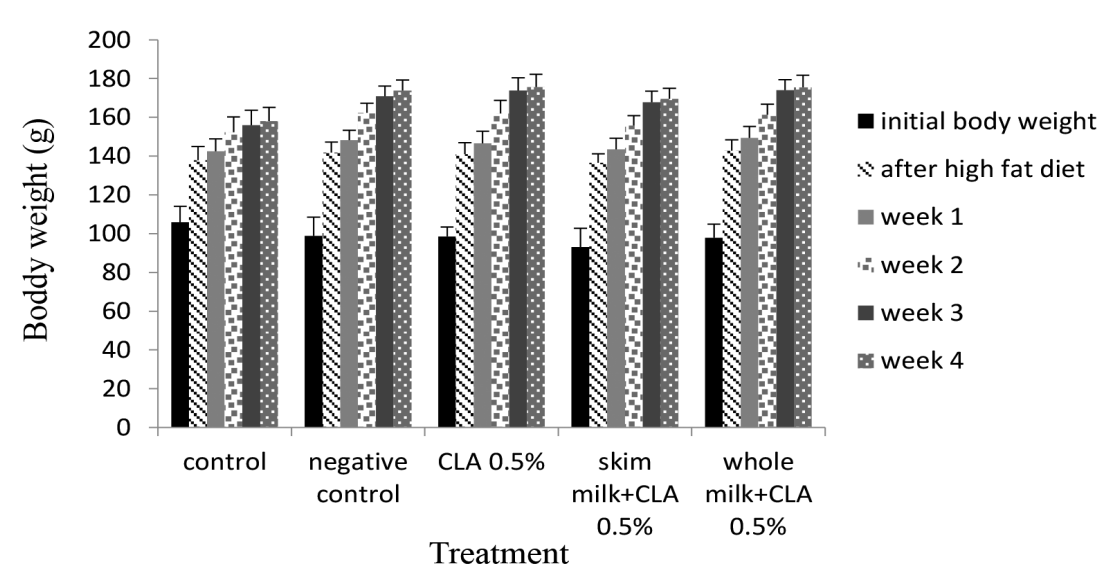

FIGURE 1. Effect of CLA supplemented milk on body weight of rats

\section{Effect of CLA-supplemented milk on lipid profile}

Serum total cholesterol, triglyceride, HDL cholesterol and LDL cholesterol were not significantly different $(\mathrm{p}<0.05)$ among high fat induced obesity rats. After 4 weeks of intervention, whole milk supplemented with $0.5 \%$ CLA group had the lowest total cholesterol, triglyceride and LDL cholesterol level as well as highest HDL cholesterol compared with other treatment groups $(\mathrm{p}<0.05)$. The cardiovascular index risk as assessed by the LDL/HDL ratio was significantly different among the group after 4 weeks of intervention $(p<0.05)$. The negative control group had higher risk of cardiovascular disease as indicated by higher LDL/HDL ratio. Among treatment group, whole milk supplemented with CLA $0.5 \%$ had the lowest LDL/HDL ratio followed by CLA $0.5 \%$ and skim milk supplemented with CLA $0.5 \%$ (TABLE 2 ). 


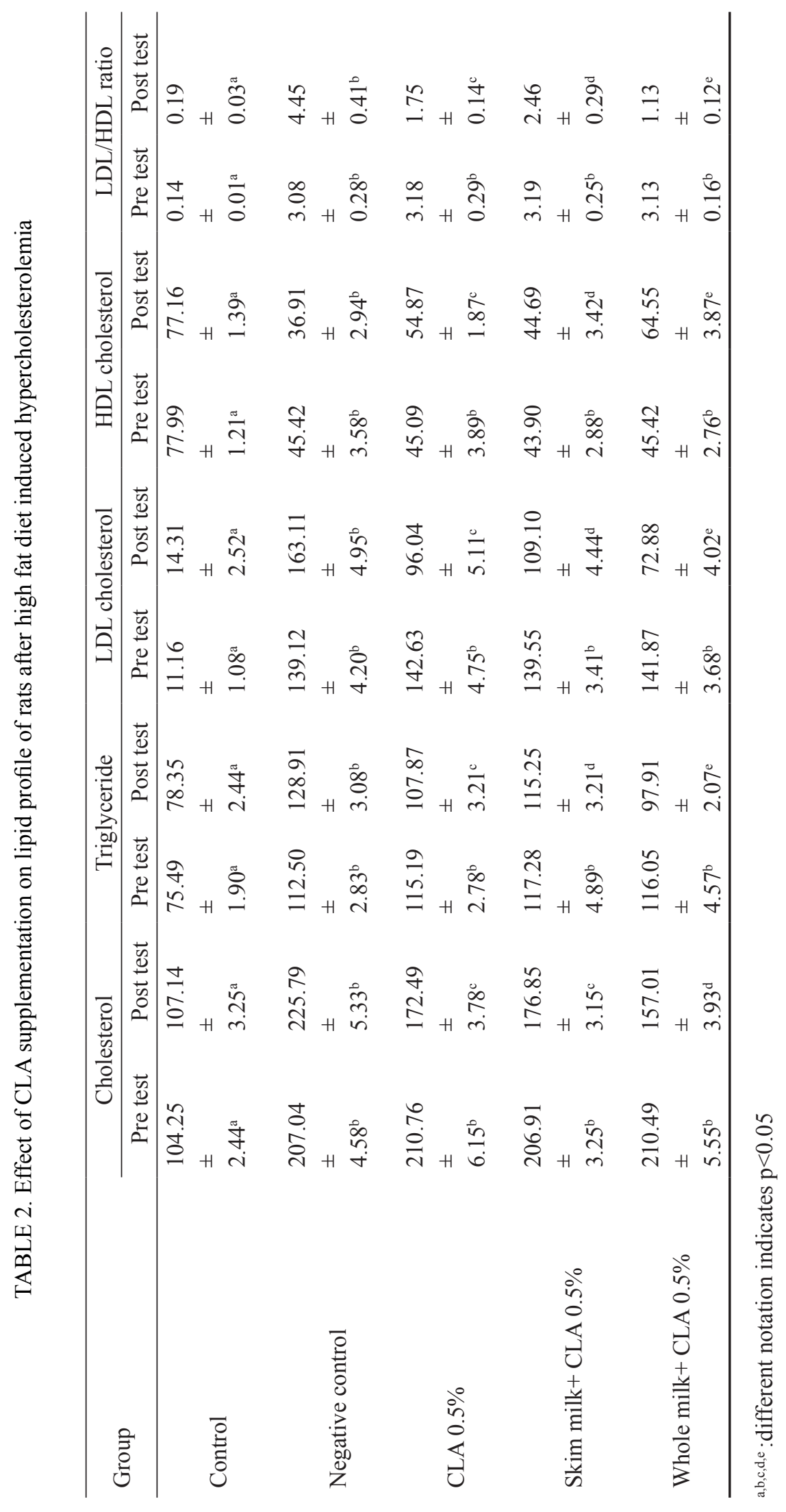




\section{DISCUSSION}

The role of food in the prevention of disease had been gained attention since $\sim 2500$ years ago when Hipocrates said "Let food be thy medicine and medicine be thy food". ${ }^{19}$ Indeed, several bioactive compounds have been identified in food and have linked with the prevention of lipid disorder, cardiovascular disease and cancer. ${ }^{20-22}$ One of the bioactive compound that has been studied in the prevention of several diseases was CLA.

Some studies have reported the beneficial effect of CLA in the prevention of cardiovascular disease in animal model received high fat diet through improvement in lipid profile such as lower level of total cholesterol, triglyceride and LDL cholesterol as well higher level of HDL cholesterol in blood after treatment with CLA. ${ }^{23,24}$ Our result also proved the impact of CLA, both in supplemented milk or not, could reduce total cholesterol by $14.5 \%$ - $25.4 \%$, triglyceride level by $1.73-15.63 \%$, LDL cholesterol by $21.82-48.63 \%$ and increase HDL cholesterol level by $1.80 \%-42.12 \%$. We also observed decreased LDL/HDL ratio, a cardiovascular risk index, ${ }^{25}$ when animal fed CLA in all treatment groups.

Despite the possitive effect on the lipid profile improvement, we did not observe any impact of CLA supplementation in body weight whether it is supplemented in milk or not. This result can be explained by the type of CLA isomer ingested in the body. It was reported that CLA isomer trans-10, cis-12, has been linked with negative effect on health such as impairment in glucose tolerance and reduced insulin sensitivity as well..$^{26,27}$ The isomer trans-10, cis-12 CLA has been associated with lower weight reducing effect compared with the cis-9, trans-11 CLA due to the ability of the trans-10, cis-12 CLA in modulating several genes involved in lipolysis and fatty acid oxidation. . $^{5,28}$
Furthermore, the dose of CLA used in this study is not met the physiological dose to promote human benefit. The CLA dose was $106 \mathrm{mg}$ in this study, whereas the estimated recommended dose of CLA that would benefited health would fall from $530 \mathrm{mg}$ to $3 \mathrm{~g}$ of CLA/day. ${ }^{29}$ Higher dose of CLA is required to induce body weight reduction in obesity state. ${ }^{30}$

\section{CONCLUSION}

In conclusion, CLA improves lipid profile in high fat induced hypercholesterolemia although no effect is observed on body weight. Further research is required to clarify the physiological mechanism of CLA in improving lipid profile in high fat induced hypercholesterolemia.

\section{ACKNOWLEDGEMENTS}

This study was partially funded by Dana Masyarakat (Community Fund), Faculty of Medicine, Universitas Gadjah Mada, Yogyakarta, Indonesia.

\section{REFERENCES}

1. Flegal KM, Carroll MD, Ogden CL, Johnson CL. Prevalence and trends in obesity among US adults, 1999-2000. JAMA 2002; 288(14):1723-7. https://doi.org/10.1001/jama.288.14.1723

2. Flegal KM, Carroll MD, Ogden CL, Curtin LR. Prevalence and trends in obesity among US adults, 1999-2008. JAMA 2010;303(3):23541.

https://doi.org/10.1001/jama.2009.2014

3. Garnett SP, Baur LA, Jones AMD, Hardy LL. Trends in the prevalence of morbid and severe obesity in Australian children aged 7-15 years, 1985-2012. PLoS One 2016; 11(5): 0154879. https://doi.org/10.1371/journal.pone.0154879 
4. Rachmi CN, Agho KE, Li M, Baur LA. Stunting, underweight and overweight in children aged 2.0-4.9 years in Indonesia: prevalence trends and associated risk factors. PLoS One 2016;11(5):e0154756.

https://doi.org/10.1371/journal.pone.0154756

5. Grundy SM, Brewer HB, Cleeman JI, Smith SC, Lenfant C, Participants for the C. Definition of metabolic syndrome: report of the National Heart, Lung, and Blood Institute/ American Heart Association Conference on Scientific Issues Related to Definition. Circ 2004;109 (3):433-8.

https://doi.org/10.1161/01.CIR.0000111245. 75752.C6

6. Wahba IM, Mak RH. Obesity and obesityinitiated metabolic syndrome: mechanistic links to chronic kidney disease. Clin J Am Soc Nephrol 2007;2(3):550-62. https://doi.org/10.2215/CJN.04071206

7. de Boer MD, Gurka MJ, Morrison JA, Woo JG. Inter-relationships between the severity of metabolic syndrome, insulin and adiponectin and their relationship to future type 2 diabetes and cardiovascular disease. Int J Obes (Lond) 2016;40(9):1353-9. https://doi.org/10.1038/ijo.2016.81

8. Ko S, Yoon S-J, Kim D, Kim A-R, Kim E-J, Seo H-Y. Metabolic risk profile and cancer in Korean men and women. J Prev Med Public Health 2016;49(3):143-52. https://doi.org/10.3961/jpmph.16.021

9. Singla P, Bardoloi A, Parkash AA. Metabolic effects of obesity: a review. World J Diabetes 2010;1(3):76-88. https://doi.org/10.4239/wjd.v1.i3.76

10. Serra D, Mera P, Malandrino MI, Mir JF, Herrero L. Mitochondrial fatty acid oxidation in obesity. Antioxid Redox Signal 2013;19(3):269-84. https://doi.org/10.1089/ars.2012.4875

11. Jung UJ, Choi M-S. Obesity and its metabolic complications: the role of adipokines and the relationship between obesity, inflammation, insulin resistance, dyslipidemia and nonalcoholic fatty liver disease. Int J Mol Sci 2014;15(4):6184-223.

https://doi.org/10.3390/ijms15046184

12. Wing RR, Lang W, Wadden TA, Safford M, Knowler WC, Bertoni AG, et al. Benefits of modest weight loss in improving cardiovascular risk factors in overweight and obese individuals with type 2 diabetes. Diabetes Care 2011;34(7):1481-6. https://doi.org/10.2337/dc10-2415

13. Steinhart $H$, Rickert $R$, Winkler $K$. Identification and analysis of conjugated linoleic acid isomers (CLA). Eur J Med Res 2003;8(8):370-2.

14. Martins SV, Lopes PA, Alfaia CM, Ribeiro VS, Guerreiro TV, Fontes CM, et al. Contents of conjugated linoleic acid isomers in ruminant-derived foods and estimation of their contribution to daily intake in Portugal. Br J Nutr 2007; 98(6):1206-13. https://doi.org/10.1017/S0007114507781448

15. Benjamin S, Prakasan P, Sreedharan S, Wright A-DG, Spener F. Pros and cons of CLA consumption: an insight from clinical evidences. Nutr Metab 2015;12:4. https://doi.org/10.1186/1743-7075-12-4

16. Bialek A, Tokarz A, Dudek A, Kazimierska $\mathrm{W}$, Bielecki W. Influence of diet enriched with conjugated linoleic acids on their distribution in tissues of rats with DMBA induced tumors. Lipids Health Dis 2010; 9:126. https://doi.org/10.1186/1476-511X-9-126

17. Tricon S, Burdge GC, Kew S, Banerjee T, Russell JJ, Jones EL, et al. Opposing effects of cis-9,trans-11 and trans-10,cis-12 conjugated linoleic acid on blood lipids in healthy humans. Am J Clin Nutr 2004; 80(3):614-20.

18. Lehnen TE, da Silva MR, Camacho A, Marcadenti A, Lehnen AM. A review on effects of conjugated linoleic fatty acid (CLA) upon body composition and energetic metabolism. J Int Soc Sports Nutr 2015;12:36. https://doi.org/10.1186/s12970-015-0097-4 
19. Hasler CM. Functional foods: benefits, concerns and challenges - a position paper from the American Council on Science and Health. J Nutr 2002;132 (12) :3772-81.

20. Kris-Etherton PM, Hecker KD, Bonanome A, Coval SM, Binkoski AE, Hilpert KF, et al. Bioactive compounds in foods: their role in the prevention of cardiovascular disease and cancer. Am J Med 2002;113 Suppl:71S-88S. https://doi.org/10.1016/S00029343(01)00995-0

21. Tamba DA, Farmawati A, Cempaka R, Wijaya YOS, Bismantara H, Danurdoro A. Effect of capcaisin plus vitamin $\mathrm{E}$ on lipid profile. Pakistan J Nutr 2014;13(9):521-6. https://doi.org/10.3923/pjn.2014.521.526

22. Harumi M, Trisna G, Odiyana N, Aulia D, Khrisnawati P, Farmawati A. Quercetin and curcumin prevent decreasing of LDL cholesterol and increasing of HDL cholesterol in high fat diet rats. Media Farm 2010;12(2):225-32.

23. Parra P, Palou A, Serra F. Moderate doses of conjugated linoleic acid reduce fat gain, maintain insulin sensitivity without impairing inflammatory adipose tissue status in mice fed a high-fat diet. Nutr Metab 2010;7:5. https://doi.org/10.1186/1743-7075-7-5

24. Joseph S V, Liu X, Wakefield A, Chouinard PY, Aukema H, Jones PJ, et al. Trans- 8 , cis10+ cis-9, trans-11-conjugated linoleic acid mixture alters body composition in Syrian golden hamsters fed a hypercholesterolaemic diet. Br J Nutr 2010;104(10):1443-9. https://doi.org/10.1017/S0007114510002345
25. Millán J, Pintó X, Mu-oz A, Zú-iga $M$, Rubiés-Prat J, Pallardo LF, et al. Lipoprotein ratios: Physiological significance and clinical usefulness in cardiovascular prevention. Vasc Health Risk Manag 2009;5:757-65.

26. Henriksen EJ, Teachey MK, Taylor ZC, Jacob S, Ptock A, Kramer K, et al. Isomer-specific actions of conjugated linoleic acid on muscle glucose transport in the obese Zucker rat. Am J Physiol Endocrinol Metab 2003;285(1):E98105.

https://doi.org/10.1152/ajpendo.00013.2003

27. Warren JM, Simon VA, Bartolini G, Erickson KL, Mackey BE, Kelley DS. Trans-10,cis-12 CLA increases liver and decreases adipose tissue lipids in mice: possible roles of specific lipid metabolism genes. Lipids 2003;38(5):497-504. https://doi.org/10.1007/s11745-003-1090-0

28. Feitoza AB, Pereira AF, da Costa NF, Ribeiro BG. Conjugated linoleic acid (CLA): effect modulation of body composition and lipid profile. Nutr Hosp 2009;24(4):422-8.

29. Blankson H, Stakkestad JA, Fagertun H, Thom E, Wadstein J, Gudmundsen O. Conjugated linoleic acid reduces body fat mass in overweight and obese humans. J Nutr 2000;130(12):2943-8.

30. Steck SE, Chalecki AM, Miller P, Conway J, Austin GL, Hardin JW, et al. Conjugated linoleic acid supplementation for twelve weeks increases lean body mass in obese humans. J Nutr 2007;137(5):1188-93. 